\title{
The presence of the father in the kangaroo method
}

\author{
A presença do pai no método canguru \\ La presencia del padre en el método canguru
}

\begin{abstract}
Thais Rosental Gabriel Lopes ${ }^{1}$ (1)
Viviane Euzébia Pereira Santos ${ }^{1}$ (1) Jovanka Bittencourt Leite de Carvalho ${ }^{1}$ (C)
\end{abstract}

1. Universidade Federal do Rio Grande do Norte. Natal, RN, Brasil
Corresponding author:

Thais Rosental Gabriel Lopes

E-mail: thaisrg12@hotmail.com.

Submitted on $12 / 10 / 2018$

Accepted on 03/27/2019.

DOI: 10.1590/2177-9465-EAN-2018-0370

\section{Abstract}

Objective: To reflect about the father's experience close to the premature son using the kangaroo method under the referential of Merleau-Ponty. Method: Theoretical-reflexive study based on the phenomenology of perception and behavior proposed by Merleau-Ponty and relevant literature. Results: To live the prematurity with the son using the kangaroo method, provides for the father to recognize himself as a being in the world. His intentions regarding the care are demonstrated through the skin to skin contact and the associated care for the newborn child. From the lived experiences, the father can exert the fullness of his paternity. Conclusion and implications for practice: By comprehending the father's way of being, acting and reacting using the kangaroo method, it will be possible to reflect upon his attitudes as caregiver and get him closer to the newborn child. Therefore, it is possible to strengthen the behaviors between father and son with the purpose of creating an emotional bond, thus allowing the inherent care regarding prematurity. Understanding the paternal behavior in the care of the premature child in the Kangaroo Method and their perceptions about care neonatal, can benefit nursing praxis from the perspective of promoting neonatal health, as well as in the prevention of diseases in relation to morbidity and Infant mortality.

Keywords: Father; Kangaroo Method; Neonatal Nursing; Humanization of Assistance; Philosophy.

\section{REsUMO}

Objetivo: Refletir sobre a vivência do pai junto ao filho prematuro no Método Canguru sob o referencial de Merleau-Ponty. Método: Estudo teórico-reflexivo baseado na Fenomenologia da Percepção e do Comportamento proposto por Merleau-Ponty e literatura pertinente. Resultados: Vivenciar a prematuridade junto ao filho no Método Canguru propicia ao pai se reconhecer como ser-no-mundo. Suas intenções acerca do cuidado são demonstradas pelo contato pele a pele e do cuidado inerente ao recém-nascido prematuro. A partir das experiências vividas, possibilita ao pai exercer sua paternidade de forma plena e significativa. Conclusão e implicações para a prática: Compreender as formas de ser, agir e reagir do pai no Método Canguru, possibilita a reflexão de suas atitudes como cuidador e aproxima-o do recém-nascido prematuro. Dessa forma, é possível edificar os comportamentos entre pai e filho no intuito de vinculá-los afetivamente e permitir os cuidados inerentes à prematuridade. Compreender o comportamento paterno nos cuidados ao filho prematuro no Método Canguru e suas percepções acerca do cuidado no período neonatal, pode beneficiar a práxis de enfermagem na perspectiva de promoção à saúde neonatal, bem como na prevenção de agravos no que tange à morbidade e mortalidade infantil.

Palavras-chave: Pai; Método Canguru; Enfermagem Neonatal; Humanização da Assistência; Filosofia.

\section{Resumen}

Objetivo: Reflexionar sobre la experiencia del padre acerca del hijo prematuro, utilizando el método canguro bajo el referencial de Merleau-Ponty. Método: Estudio teórico-reflexivo basado en la fenomenología de la percepción y el comportamiento propuesto por Merleau-Ponty y la literatura pertinente. Resultados: Convivir con la vida del hijo prematuro, utilizando el método canguro, es favorable para que el padre se reconozca como un ser en el mundo. Sus intenciones con respecto al cuidado se demuestran a través del contacto de piel con piel y del cuidado asociado al niño recién nacido. De las experiencias vividas, el padre puede ejercer la plenitud de su paternidad. Conclusión e implicaciones para la práctica: Al comprender la manera del padre de ser, actuar y reaccionar, usando el método del canguro, será posible reflexionar sobre sus actitudes como cuidador y acercarlo al niño recién nacido. Por lo tanto, es posible fortalecer los comportamientos entre padre e hijo con el propósito de crear un vínculo afectivo, permitiendo así el cuidado inherente con respecto a la prematuridad. La comprensión del comportamiento paternal en el cuidado del niño prematuro en el método canguro y sus percepciones sobre la atención en el período neonata pueden beneficiar la praxis en enfermería, desde la perspectiva de promover salud neonatal, así como en la prevención de enfermedades en relación a la morbilidad y mortalidad infantil.

Palabras clave: Padre; Método Canguro; Enfermería Neonatal; Humanización de la Atención; Filosofía. 


\section{INTRODUCTION}

In the context of neonatal care, the Kangaroo Method (MC) stands out as a humanized care in the scenario of prematurity, which occurs when gestation is interrupted before the 37th week of the gestational cycle, as well as the birth of a premature infant weighing 2,500 grams or less. ${ }^{1}$

The number of premature babies grows annually. In 2016, the World Health Organization (WHO) has shown that among live births, approximately 15 million newborns were premature, which is a serious public health problem. ${ }^{3}$ In that same year, data from the United Nations Children's Fund (UNICEF) showed that in Brazil, the number of infant deaths occurred in the neonatal period was $70 \%$, and thus was considered the second cause of mortality. ${ }^{2}$

In the face of expressive indicators that imply neonatal morbidity and mortality, the Kangaroo Method, through the Standard of Humanized Attention to the Low Weight Newborn, aims to humanize and qualify neonatal care. In Brazil, since 1999, this method is considered a public health policy, and the nomenclature is adapted to Kangaroo Method. ${ }^{3}$ This assistance modality first appeared in Colombia in 1979 as a proposal to improve the quality of life and decrease the mortality of premature infants. The absence of adequate material resources for the care, motivated pediatricians to position the newborns on the maternal thorax, inspired by the marsupial method of the females that carry the puppies next to the body until their physiological maturation.

The Kangaroo Method is divided into three stages. Initially, it occurs in the Neonatal Intensive Care Unit (NICU), where parents and family members are instructed to perform small touches on the newborn's skin until they feel secure in positioning the child on the chest in skin-to-skin contact. Subsequently, after reaching the necessary weight and clinical stability, the premature infant is referred to the second stage in the Kangaroo Intermediate Care Unit (UCINCa). ${ }^{4}$ In this environment, the baby is accompanied uninterruptedly by the parents and family in the daily care, who are stimulated to realize the positioning as much time as they have. ${ }^{5}$ The baby remains in joint lodging with the mother until her discharge, for continuity of skin-to-skin contact and for the specific care in the third stage of the method. ${ }^{5-6}$

Throughout the stages that contemplate the Kangaroo Method, the participation of the father and relatives is of paramount importance and makes the proposal of humanized care feasible. The paternal presence is highlighted by the Brazilian ministerial standards, since like the mother, it is also necessary to introduce him to neonatal care, considering the relevance of his participation to the benefits of the parent-child triad. ${ }^{7}$

Although childcare is historically linked to the female figure, the role of the father has been rebuilt in today's society. ${ }^{8}$ In the context of childcare in the contemporary nuclear family structure, man has been shown to be participatory in various aspects of the child's life, exercising co-parenting on the health and well-being of the premature child. Scientific evidence demonstrates that shared care contributes significantly to child growth and development at various stages of life. ${ }^{9}$
Caring for the child in the Kangaroo Method is still a challenge for the father, a fact associated with personal, social, cultural and institutional factors. The necessary estrangement of the premature child in the early stages of the Kangaroo Method leads the father to have fears and uncertainties about his clinical evolution; doubts related to the care of the premature child and concerns about the child's survival after hospital discharge. ${ }^{10}$ In addition to these factors, there are still incipient studies in the national and international literature on paternal involvement in the care of the premature infant. ${ }^{11,7-12}$

The reflection on the experience of the father in the kangaroo method aims at helping to understand the effectiveness of his participation in the care of premature newborns given the benefits that the method contemplates, namely: thermal, respiratory and cardiac stability; promotion of growth and development; motor and cognitive stimulation; stress reduction and pain of the newborn; decreased chances of nosocomial infection; and empowering the father in caring for the premature baby. ${ }^{5}$ In these circumstances, the father is considered as a being-in-situation, since it is in the specific context directed to the child in a premature situation, in which the body meets the other body, which is evidenced by skin-to-skin contact.

In view of the above, the possibility of reflection on the being-of-father in the Kangaroo Method is emphasized. For this, the following question is pointed out: How does the father experience the Kangaroo Method with the premature child? Thus, this study aimed to reflect on the experience of the father in the care given to the premature child in the stages of the Kangaroo Method, based on the Phenomenology of Perception and the Phenomenology of Behavior proposed by Merleau-Ponty and relevant literature.

\section{Theoretical and philosophical conceptions on the phenomenology of Perception and Behavior}

The historian and professor of philosophy, Maurice Merleau-Ponty (1908-1961) was born in the French city of Rochefort-Sur-Mer. His father died in World War I and he grew up with his mother and two brothers. During his studies, still young, he was integrated to the chain of phenomenological thinkers, successors of the father of the Phenomenology Edmund Husserl (1859-1938). ${ }^{13}$

Among the proposals of the phenomenological current is "to return to own things" as they present themselves, daily, in relation to the world. Consciousness is always an awareness of something, being the object always the object for a consciousness, and thus a phenomenon. Thus Merleau-Ponty thoughts affirm that consciousness is linked to a body which, through intentions from the mind, interact with the world, which can be defined as corporeality. ${ }^{13}$

Considered one of the greatest French existentialists of the twentieth century, Merleau-Ponty worried about the existence of man rather than essence. These thoughts are linked to the moment experienced, in the midst of the socioeconomic crisis and culture through which Europe passed after the Second World War. This situation directly interfered in the philosophical 
conceptions on the man and his experiences lived in the world.

On these experiences, Merleau-Ponty presents his view of the human being-in-the-world both as regards his behavior and his perception of worldly things. These are described in his main works: The Behavioral Structure $(1942 / 2006)^{13}$ and the Phenomenology of Perception (1945/2006) ${ }^{12}$. Anchored in Merleau-Ponty's ontological view that human perception and behavior occur as man interacts with "things" in the world, the relation of such a philosophical approach to the perception and behavior of the father is established by experiencing the Kangaroo Method with premature child.

\section{The father's perception of the premature child in the Kangaroo Method}

The prematurity of the child presents itself to the father as an event, most of the times, unexpected. In these conditions, the experience of care can give him and other family members the feeling of a challenge. In the imaginary of those who accompany the intrauterine development of the baby, the birth of the new family entity is associated with his accompanied in the home environment. However, they are faced with a fragile, small baby, who demands an interventionist assistance and multiprofessional team. Under these circumstances, it is irrevocable that the follow-up of the premature baby is destined to the hospital space, as well as the need for parents and family members to adapt to the new routine of care for the new family member.

In this dimension, the Kangaroo Method proposal is a strategy that aims to minimize the distance between the father and his premature child, hospitalized with the mother in the first stages of the method. These actions contribute to the strengthening of the affective bond between the parent-child triad. ${ }^{14-15}$ The paternal figure has an indispensable importance for the restoration of the family structure, in the support and division of the responsibilities of the care of the child with the companion, with emphasis for the continuity of the third stage of the method, after the discharge of the baby born prematurely.

The father's approach and perception regarding prematurity of the child occurs in a primary way. It will occur most often after childbirth and, in the face of such circumstance, may trigger antagonistic feelings in the father, such as the happiness of the encounter with the child and fears of its clinical evolution. ${ }^{14-15-16}$ The paternal sensations, according to the Merleau-Pontyan perspective, are due to the world not yet perceived by the father, and to the first contact with a universe of prematurity, hitherto unknown.

Living with the premature child enables the father to perceive the Kangaroo Method as a way to watch the newborn in his entirety. Faced with this circumstance, the father is no longer a man-in-himself, but the man-in-situation. And, this interaction with the child builds the relationships/behaviors between both, and thus provides not only benefits indicated by the method, but also the awareness of the importance of their presence in the Kangaroo Method. Such reflection is in keeping with Merleau-Ponty's conceptions, which affirm that man perceives himself as a body in the encounter with the body-other. In addition, the philosopher demonstrates that through the body perceptions are possible. ${ }^{13}$

The body is the instrument of man's contact with the other, and through the Kangaroo Method the father is present in the world. When experiencing skin-to-skin contact with the premature child, the father uses tactile, olfactory, visual, and auditory sensitivities. The touch on the skin promotes safety and affection for the premature child, and by placing it on his chest, the man perceives himself in his visibility.

When reflecting on the paternal attitude in performing the Kangaroo Method, there is no way to differentiate who touches and who is touched, or who receives the touch is touching through the body. From Merleau-Ponty's point of view, these senses reveal the body in attitude, as well as embrace the corporeal nature and perceive the being-in-the-world. ${ }^{13}$

\section{The lived experience and the behavior of the father in the Kangaroo Method}

The experience of the father in performing the Kangaroo Method allows one to fully, meaningfully and consciously experience paternity of their attitudes about care. The act of caring is inherent to the human being, for it is through this that the survival of man occurs. This thought meets the Merleau-Pontyan principles, which point out that all action is preceded by intention, of a meaning to be revealed by meanings. ${ }^{13}$

Through the awareness of his attitudes towards the premature child, the father is able to get the notion of his behavior. He adapts to the care inherent in premature infants, and thus shapes his attitudes toward the premature newborn. Behavior is modified from the experiences of being. This dynamism is defined by Merleau-Ponty as the consciousness of being existing in the world. ${ }^{13}$

The body performs the intermediation between the world and the being that is in this space. Man is never totally free to act in the world presented to him, for even before he is "thrown" into this world, he already has his constitutions. ${ }^{13}$ The same happens with the father, when faced with the hospital environment, where he remains with the premature child until he is clinically stable. During the first stages of the Kangaroo Method, the father is "thrown" into a place with pre-established rules and regulations, as well as in the relationship with health professionals and family members of other preterm infants, until the child is released into the family environment.

This moment of transition may evoke conflicting feelings for the father (Figure 1), however, it is necessary to become accustomed to the presented reality. It is considered that this situation allows the father to manifest himself with new ways of acting as being-in-the-world, since he must live not only with the fear and insecurity of the child's clinical evolution in the face of prematurity, but also with the new imperative routine.

In a reflexive way, the dynamism between the perception and the behavior of the father, the interactions of the being-father as an 


\section{THE BEING-FATHER IN THE WORLD IN THE KANGAROO METHOD}

\section{PERCEPTIONS}<smiles>C1CCCCC1</smiles>
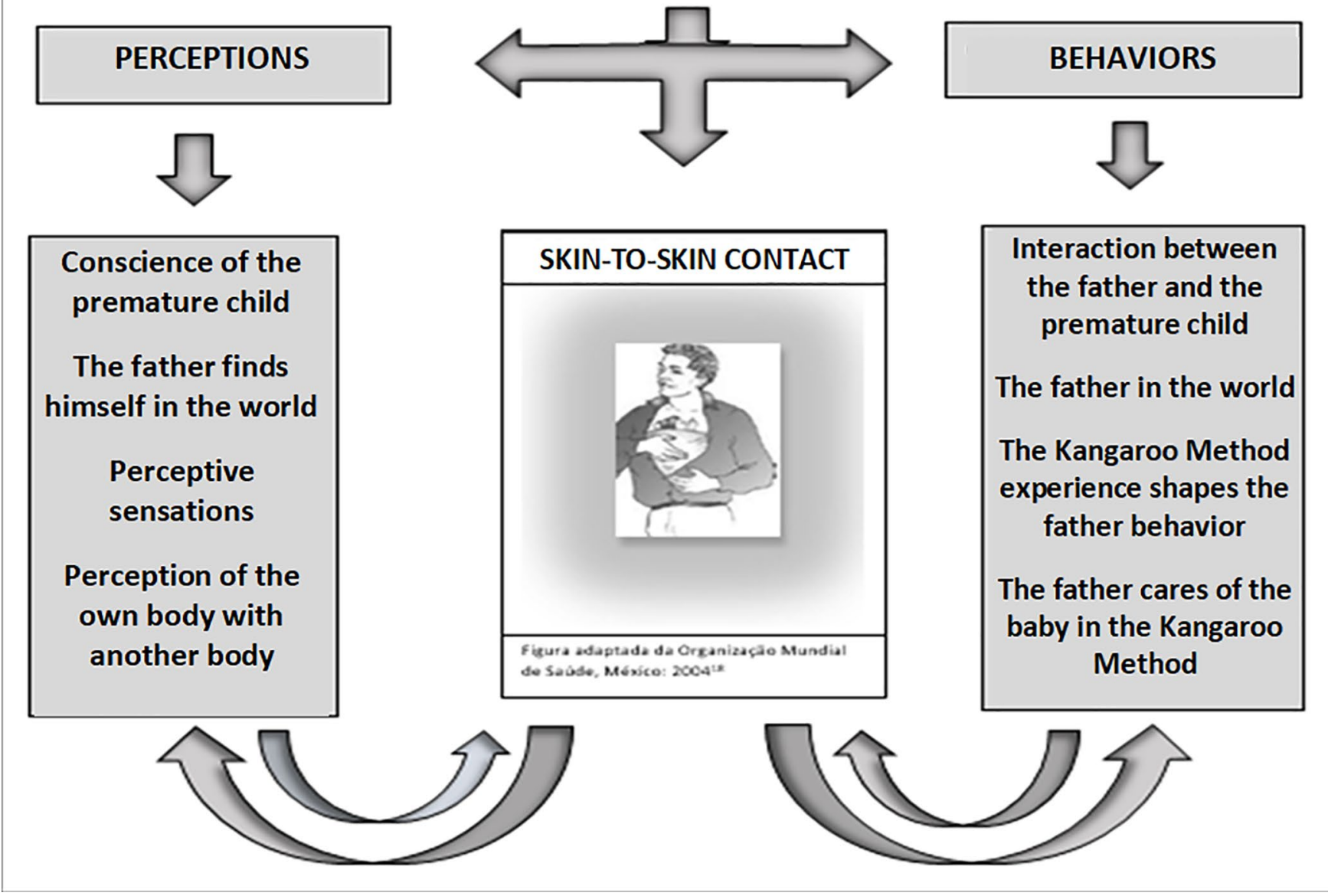

individual that is perceived when performing skin-to-skin contact and acts in daily care with the child premature when performing the Kangaroo Method in the merleau-pontyana perspective.

\section{FINAL CONSIDERATIONS}

In order to understand the experience of the father with the premature child in the Kangaroo Method, it is necessary to perceive how the experience of the care of the premature child is given, as well as to glimpse its acts from the relational/behavioral dimension with the other, to the measure which relates to the premature child and acts in his care.

The father's experience in the Kangaroo Method occurs dynamically, through acts, which are not dissociated from the consciousness of being-in-the-world. Touch, as tactile perception, allows the father sensations and meanings that modify his Behavior, for, according to the Merleau-Pontyana perspective, such acts comprise an opening to the other.

By means of the subjective manifestations that interfere in the parental attitudes with the premature child when realizing the
Kangaroo Method, it is possible to perceive the lived experiences like existential subject. In this sense, it becomes a challenge for the health professional, especially nursing ones, to understand the intersubjectivity of the father with the premature newborn, his attitudes and anxieties regarding care with the child as a presented phenomenon.

Thus, the aspects evidenced in this theoretical-reflexive study aim to provide nursing professionals with a reflection of the praxis in the care given to the father and premature child assisted in the hospital and home environment, given the importance of valuing and approaching the paternal figure in the care of the child premature, with a view to improving care at all stages that permeate the Kangaroo Method.

\section{REFERENCES}

1. World Health Organization (WHO). Recommendations on interventions to improve preterm birth outcomes. Geneva:World Health Organization; 2015.

2. World Health Organization (WHO). Levels and trends in child mortality 2015. Geneva: World Health Organization; 2015. 
3. Lanata CF, Fischer-Walker CL, Olascoaga AC, Torres CX, Aryee MJ, Black RE; Child Health Epidemiology Reference Group of the World Health Organization and UNICEF. Global causes of diarrheal disease mortality in children $<5$ years of age: a systematic review. PLoS One [Internet]. 2013 Sep; [cited 2018 Jul 18]; 8(9):e72788. Available from: https://www.ncbi.nlm. nih.gov/pubmed/24023773

4. Aires LCP, Santos EVKA, Costa R, Borck M, Custódio ZAO. Seguimento do bebê na atenção básica: interface com a terceira etapa do método canguru. Rev Gaúcha Enferm [Internet].2015;36(no.spe):224-32. Available from: http://www.scielo.br/scielo.php?script=sci_arttext\&pid=S198314472015000500224\&lng=en\&nrm=iso

5. Zampieri MFM, Guesser JC, Buendgens BB, Junckes JM, Rodrigues IG. O significado de ser pai na ótica de casais grávidos: limitações e facilidades. Rev Eletr Enferm [Internet]. 2012 Jul/Sep; [cited 2018 Jul 18]; 14(3):483-93. Available from: http://www.fen.ufg.br/fen_revista/v14/n3/pdf//v14n3a04.pdf. DOI: https://doi.org/10.5216/ree.v14i3.12244

6. Jesus NC, Vieira BDG, Alves VH, Rodrigues DP, Souza RMP, Paiva ED. The experience of the kangaroo method: the perception of the father.J Nurs UFPE On Line (Recife) [Internet]. 2015 Jul; [cited 2018 Jul 18]; 9(7):8542-50. Available from: https://periodicos.ufpe.br/revistas/ revistaenfermagem/article/view/10626. DOI: https://doi.org/10.5205/19818963-v9i7a10626p8542-8550-2015

7. Silva SO, Budô MLD, Silva MM. Concepções e Práticas de Cuidado na Visão de Homens. Texto Contexto Enferm (Florianópolis) [Internet]. 2013 Apr/Jun; [cited 2018 Jul 14]; 22(2):389-96. Available from: http://www. scielo.br/pdf/tce/v22n2/v22n2a15. DOI: http://dx.doi.org/10.1590/S010407072013000200015

8. Piccinini CA, Levandowski DC, Gomes AG, Lindenmeyer D, Lopes RS. Expectativas e sentimentos de pais em relação ao bebê durante a gestação. Estud Psicol (Campinas) [Internet]. 2009 Jul/Sep; [cited 2018 Jul 18]; 26(3):373-82. Available from: www.scielo.br/pdf/estpsi/v26n3/v26n3a10. pdf. DOI: http://dx.doi.org/10.1590/S0103-166X2009000300010

9. Souza PM, Ramos MS, Pontes FARP, Silva SSC. Coparentalidade: um estudo de revisão sistemática da Literatura. Estilos Clín (São Paulo) [Internet].2016 Sep/Dec; [cited 2018 Jul 14];21(3):700-20. Available from: http://www.revistas.usp.br/estic/article/view/131172/127602. DOI: https:// doi.org/10.11606/issn.1981-1624.v21i3p700-720
10. Machado MED, Santos ND, Christoffel MM. (Re) cognizing the masculine participation in kangaroo method: an interface with the assisten. Ciênc Cuidado Saúde [Internet]. 2013 Jul/Sep; [cited 2018 Jul 13]; 12(3):461-8. Available from: http://www.periodicos.uem.br/ ojs/index.php/CiencCuidSaude/article/view/11722/pdf. DOI: http:// dx.doi.org/10.4025/cienccuidsaude.v12i3.11722

11. Barcellos AA, Zani AV. Experience of the father the son's premature birth: integrative review. J Health Biol Sci [Internet]. 2017 Jun [cited 2018 Jul 14]; 5(3):277-85. Available from: http://periodicos. unichristus.edu.br/index.php/jhbs/article/view/1198/452. DOI: http:// dx.doi.org/10.12662/2317-3076jhbs.v5i3.1198.p277-285.2017

12. Merleau-Ponty M. Fenomenologia da percepção. 3a ed. São Paulo: Martins Fontes; 2006

13. Merleau-Ponty M. A Estrutura do comportamento. 3a ed. São Paulo: Martins Fontes ; 2006.

14. Sá Neto JA, Rodrigues BMRD. Technology as a foundation of neonatal care. Texto Contexto Enferm [Internet]. 2010 Apr/Jun; [cited 2018 Jul 15]; 19(2):372-7. Available from: http://www.scielo. br/pdf/tce/v19n2/20.pdf. DOI: http://dx.doi.org/10.1590/S010407072010000200020

15. Feeley N, Waitzer E, Sherrard K, Boisvert L, Zelkowitz . Father's perceptions of the barriers and facilitators to their involvement with their newborn hospitalized in the neonatal intensive care unit. $J$ Clin Nurs [Internet]. 2013 Feb; [cited 2018 Jul 14]; 33(3-4):521-30. Available from: http://onlinelibrary.wiley.com/doi/10.1111/j.13652702.2012.04231.x/epdf. DOI: https://doi.org/10.1111/j.13652702.2012.04231.x

16. Toma TS. Da intuição às políticas públicas: a jornada para incorporação do Método Canguru no cuidado ao recém-nascido de baixo peso. BIS Bol Inst Saúde [Internet]. 2012 Jul; [cited 2018 Jul 15] 13(3):231-8. Available from: http://periodicos.ses.sp.bvs.br/scielo. php?script=sci_arttext\&pid=S1518-18122012000300006\&lng=pt

17. Organización Mundial de la Salud (OMS). Departamento de Salud Reproductiva e Investigaciones Conexas. Método Madre Canguro: guía práctica. Ginebra: Organización Mundial de la Salud; 2003. 62 p. 